\title{
Article \\ Subcellular Localization of Fad1p in Saccharomyces cerevisiae: A Choice at Post-Transcriptional Level?
}

\author{
Francesco Bruni ${ }^{1}{ }^{\oplus}$, Teresa Anna Giancaspero ${ }^{1}$, Mislav Oreb ${ }^{2} \oplus$, Maria Tolomeo ${ }^{1}$, Piero Leone ${ }^{1}$, Eckhard Boles ${ }^{2}$, \\ Marina Roberti ${ }^{1}$, Michele Caselle ${ }^{3}$ (D) and Maria Barile ${ }^{1, *}$ (D) \\ 1 Department of Biosciences, Biotechnologies and Biopharmaceutics, University of Bari Aldo Moro, \\ Via Orabona 4, 70125 Bari, Italy; francesco.bruni@uniba.it (F.B.); teresagiancaspero@virgilio.it (T.A.G.); \\ maria.tolomeo@uniba.it (M.T.); pieroleone87@gmail.com (P.L.); marina.roberti@uniba.it (M.R.) \\ 2 Institute of Molecular Biosciences, Goethe-University Frankfurt, Max-von-Laue-Str. 9, \\ 60438 Frankfurt am Main, Germany; m.oreb@bio.uni-frankfurt.de (M.O.); e.boles@bio.uni-frankfurt.de (E.B.) \\ 3 Physics Department, University of Turin and INFN, Via P. Giuria 1, 10125 Turin, Italy; michele.caselle@unito.it \\ * Correspondence: maria.barile@uniba.it; Tel.: +39-080-544-3604
}

Citation: Bruni, F.; Giancaspero, T.A.; Oreb, M.; Tolomeo, M.; Leone, P.; Boles, E.; Roberti, M.; Caselle, M.; Barile, M. Subcellular Localization of Fad1p in Saccharomyces cerevisiae: A Choice at Post-Transcriptional Level? Life 2021, 11, 967. https:// doi.org/10.3390/life11090967

Academic Editor: Theodoros Rampias

Received: 29 July 2021

Accepted: 13 September 2021

Published: 14 September 2021

Publisher's Note: MDPI stays neutral with regard to jurisdictional claims in published maps and institutional affiliations.

Copyright: (c) 2021 by the authors. Licensee MDPI, Basel, Switzerland. This article is an open access article distributed under the terms and conditions of the Creative Commons Attribution (CC BY) license (https:// creativecommons.org/licenses/by/ $4.0 /)$.

\begin{abstract}
FAD synthase is the last enzyme in the pathway that converts riboflavin into FAD. In Saccharomyces cerevisiae, the gene encoding for FAD synthase is FAD1, from which a sole protein product (Fad1p) is expected to be generated. In this work, we showed that a natural Fad1p exists in yeast mitochondria and that, in its recombinant form, the protein is able, per se, to both enter mitochondria and to be destined to cytosol. Thus, we propose that FAD1 generates two echoformsthat is, two identical proteins addressed to different subcellular compartments. To shed light on the mechanism underlying the subcellular destination of Fad1p, the $3^{\prime}$ region of FAD1 mRNA was analyzed by $3^{\prime}$ RACE experiments, which revealed the existence of (at least) two FAD1 transcripts with different $3^{\prime}$ UTRs, the short one being $128 \mathrm{bp}$ and the long one being $759 \mathrm{bp}$. Bioinformatic analysis on these $3^{\prime}$ UTRs allowed us to predict the existence of a cis-acting mitochondrial localization motif, present in both the transcripts and, presumably, involved in protein targeting based on the $3^{\prime} \mathrm{UTR}$ context. Here, we propose that the long FAD1 transcript might be responsible for the generation of mitochondrial Fad1p echoform.
\end{abstract}

Keywords: FAD synthase; FAD1; mitochondria localization; Saccharomyces cerevisiae; mRNA; mitochondrial localization motif

\section{Introduction}

Riboflavin (Rf or vitamin B2) deficiency in humans and experimental animals has been linked to several diseases, such as cancer, cardiovascular diseases, anemia, abnormal fetal development, different neuromuscular and neurological disorders, some of which are treatable with high doses of riboflavin. Among the latter, there are the multiple acyl-CoA dehydrogenase deficiency (MADD) and the Brown-Vialetto-Van Laere syndrome (BVVLS) (see [1] and refs therein). The role of this vitamin in cell metabolism depends on its conversion into flavin mononucleotide (FMN) and flavin adenine dinucleotide (FAD), which are the redox cofactors of a large number of dehydrogenases, reductases, and oxidases. Most of these flavoenzymes are compartmented in the cellular organelles, where they are involved in energy production and redox homeostasis as well as in different cellular regulatory events including protein folding, apoptosis, and chromatin remodeling [2-4]. The relevance of such processes merits further research aimed to better describe flavin homeostasis and flavoenzyme biogenesis, especially in those organisms that can be simple and suitable models for human pathologies. The conservation of the main biological processes within all eukaryotes, together with the possibility of simple and quick genetic manipulation, make the budding yeast, Saccharomyces cerevisiae, a suitable model to understand the molecular mechanisms underlying human diseases [5-8]. 
Yeasts, as well as other fungi, plants and bacteria, have the ability either to synthesize Rf de novo or to take it from outside, whereas mammals must obtain Rf from diet. The first eukaryotic gene coding for a cellular Rf transporter was identified in S. cerevisiae as the product of the MCH5 gene [9]. More recently, three human Rf transporters have been cloned and characterized; they belong to a novel family of Rf transporters, namely, RFVT/SLC52, which exhibit no significant similarity to Mch5p [10,11]. Mutations in RFVTs have been recently linked to BVVLS, a neurodegenerative disorder characterized by cranial nerve deficits, bilateral sensorineural deafness, respiratory insufficiencies, and the degeneration of some spinal cord neurons [1,12].

Intracellular conversion of Rf to FAD is a ubiquitous pathway and occurs via the sequential actions of ATP:riboflavin 5'-phosphotransferase or riboflavin kinase (RFK, EC 2.7.1.26), which phosphorylates the vitamin into FMN, and of ATP:FMN adenylyl transferase or FAD synthase (FADS, EC 2.7.7.2) that adenylates FMN to FAD. Eukaryotes generally use two different enzymes for FAD production, whereas most prokaryotes depend on a single bifunctional enzyme $[13,14]$. The first eukaryotic genes encoding for RFK and FADS were identified in S. cerevisiae and named FMN1 [15] and FAD1 [16], respectively.

Fmn1p is a $24.5 \mathrm{kDa}$ protein showing a sequence and structure similarity to the RKF-module of prokaryotic FADS and appears largely conserved through evolution. Immunoblotting analysis of subcellular fractions revealed that Fmn1p is localized in microsomes and in mitochondria [15]. Orthologs of S. cerevisiae FMN1 have been cloned and the corresponding proteins purified from the yeast Schizosaccharomyces pombe and from Homo sapiens. The crystal structures of both these proteins have been solved, revealing a novel ATP and Rf-binding fold [17-19].

Fad1p, the sole known protein isoform generated by S. cerevisiae FAD1 gene, is a 35.5-kDa soluble enzyme that is essential for yeast life, whose crystal structure has been solved in a complex with FAD in the active site [20]. Fad1p is a single-domain monofunctional enzyme belonging to the $3^{\prime}$-phosphoadenosine $5^{\prime}$-phosphosulfate (PAPS) reductase family and shows little or no sequence similarity to the prokaryotic FAD-forming enzymes. The human gene for FADS, named FLAD1 [14,21], generates different alternatively spliced transcripts encoding different isoforms, most of them containing the PAPS reductase domain fused with an N-terminal molybdopterin-binding (MPTb) domain with FAD hydrolyzing activity [22].

Our group previously demonstrated that $S$. cerevisiae mitochondria are able to catalyze FAD hydrolysis via enzymatic activity, which is different from the already characterized NUDIX hydrolases and regulated by the mitochondrial NAD redox status [23].

The relevance of FLAD1, postulated in our previous papers [24,25], emerged in 2016 when FLAD1 was identified as a novel Riboflavin-responsive MADD disease gene [26]. MADD defines a heterogeneous class of lipid storage myopathies associated with impaired fatty acid, amino acid and choline metabolisms [27]. In the frame of these studies, a novel isoform containing the sole PAPS domain, hFADS6, was identified and then characterized in some detail [28]. The homology modeling of the PAPS reductase domain of human FADS was performed using the orthologue from Candida glabrata as a template [28].

The simultaneous presence in the same cell of the different FLAD1 transcripts is in line with a possible different subcellular localization for the different isoforms in mammals. Consistently, the existence of distinct cytosolic, nuclear and mitochondrial FADS was demonstrated in different rat models [29,30]. The human transcript variant 1 encodes a $65.3 \mathrm{kDa}$ protein, hFADS1, which contains a predictable mitochondrial-targeting peptide [21]. Mitochondrial localization of hFADS1 was proven in vitro by mitochondrial import assay and confocal microscopy [29].

Mitochondrial supply of FAD is crucial also in yeast, where it is expected to be delivered to a number of nascent client apo-flavoenzymes [31]. This occurs in some cases, such as for the flavoprotein subunit of succinate dehydrogenase (Sdh1p), via an autocatalytic covalent flavinylation mechanism, which could be assisted by ancillary proteins [32-36]. 
The first eukaryotic gene encoding for a mitochondrial FAD translocator was identified in S. cerevisiae and named FLX1, whose human orthologue is SLC25A32. Interestingly, mutations in the SLC25A32 gene have been identified as the cause for RR-MADD [37,38], thus confirming the essential role of flavin cofactor supply for mitochondrial proteome.

The existence of a mitochondrial FADS isoform in yeast is still controversial as well as the physiological role of the mitochondrial FAD translocator, Flx1p. Initially, it was reported that FAD is synthesized by Fad1p exclusively in the cytosol [16] and, consequently, imported into mitochondria via Flx1p [39]. However, results from our laboratory showed that, besides in the cytosol, FAD-forming activities can be specifically revealed in mitochondria, entailing FAD precursors uptake in mitochondria and mitochondrial FAD export to cytosol via Flx1p [40,41]. Moreover, FAD movement across the mitochondrial membrane catalyzed by Flx1p plays an additional regulatory role on apo-Sdh1p biogenesis at the post-transcriptional level [42].

As a matter of fact, the protein responsible for FAD synthesis in S. cerevisiae mitochondria remains to be identified and characterized. In this paper, we report the existence of $S$. cerevisiae Fad1p as two distinct echoforms localized to both cytosol and mitochondria, and the presence of two populations of FAD1 mRNAs, which differ for their $3^{\prime} U T R s$. Whether and how the $3^{\prime}$ UTRs play a role in the mechanism that destines Fad1p to either cytosol or mitochondria will be dealt with.

\section{Materials and Methods}

\subsection{Materials}

All reagents and enzymes were from Sigma-Aldrich (St. Louis, MO, USA), ThermoFisher Scientific (Waltham, MA, USA) and Merck KGaA (Darmstadt, Germany). Zymolyase was from MP Biomedicals (Aurora, OH, USA). Bacto Yeast Extract and Yeast Nitrogen base were from BD Difco (Franklin Lakes, NJ, USA). Monoclonal antibody against STREP-tag ( $\alpha$-STREP) was obtained from IBA Lifesciences (Göttingen, Germany), monoclonal antibody against actin ( $\alpha$-ACTIN) was from Abcam (Cambridge, MA, USA), secondary anti-rabbit or anti-mouse IgG antibodies conjugated with peroxidase were from ThermoFisher Scientific (Waltham, MA, USA). The RNeasy Midi Kit was from Qiagen (Hilden, Germany). The enhanced AMV Reverse transcriptase kit was from Sigma-Aldrich (St. Louis, MO, USA). The Dynabeads mRNA Purification kit was from Invitrogen (Waltham, MA, USA). The Wizard SV Gel and PCR Clean-up system was from Promega (Madison, WI, USA).

\subsection{Yeast Strains and Recombinant Multicopy Plasmids}

The wild-type $S$. cerevisiae strain CEN.PK113-13D (also named EBY157, WT, or K26; genotypes $M A T \alpha, M A L 2-8^{c}$, SUC2 and ura3-52) was previously described in [40,42]. The CENPK2-1C, derived from the CEN.PK yeast series, was used as a recipient strain to express a recombinant Fad1p carrying a STREP tag at the N- or C-terminal end. To construct the multicopy plasmids p426HXT7-FAD1-STREP, p426-MET25-FAD1-STREP, and p426-MET25STREP-FAD1, the FAD1 gene was cloned by PCR with a selected pair of primers designed to amplify the complete FAD1 open reading frame (ORF), skipping the contiguous $5^{\prime}$ and $3^{\prime}$ UTR regions. The amplified fragments were cloned into the multicopy plasmid p426HXT7-STREP or p426-MET25-STREP using the standard gap-repair procedure. In these vectors, the recombinant FAD1 construct, encoding Fad1p fused to the STREP tag (Trp-SerHis-Pro-Gln-Phe-Glu-Lys) at the N- or C-terminal end, was placed between the HXT7 or the MET25 promoter and CYC1 terminator. The transformation of the CEN.PK113-13D and CENPK2-1C strains with the recombinant or empty vectors was carried out according to the frozen competent cell procedure [43]; the transformed strains were selected for the presence of URA3 genetic marker, which confers the ability to grow in a minimal synthetic liquid medium (SM, $6.7 \mathrm{~g} / \mathrm{L}$ yeast nitrogen base supplemented with $25 \mathrm{mM}$ Histidine, $0.44 \mathrm{mM}$ Leucin and $0.19 \mathrm{mM}$ Tryptophan) without uracil. All the transformed strains used in this study are summarized in Table 1. 
Table 1. S. cerevisiae strains used in this study.

\begin{tabular}{ll}
\hline \multicolumn{1}{c}{ Strain } & \multicolumn{1}{c}{ Multicopy Plasmid } \\
\hline CEN.PK113-13D (EBY157, WT, K26) & $/$ \\
K26 CTR & p426-HXT7-STREP \\
K26 ${ }^{\text {FAD1-STREP }}$ & p426-HXT7-FAD1-STREP \\
CENPK2-1C FAD1-STREP $_{\text {CENPK2-1C }}^{\text {STREP-FAD1 }}$ & p426-MET25-FAD1-STREP \\
& p426-MET25-STREP-FAD1 \\
\hline
\end{tabular}

\subsection{Media and Growth Conditions}

The wild-type $\mathrm{K} 26$ cells were grown aerobically at $30{ }^{\circ} \mathrm{C}$ with constant shaking in rich liquid medium (YEP, $10 \mathrm{~g} / \mathrm{L}$ yeast extract, $20 \mathrm{~g} / \mathrm{L}$ Bacto Peptone). The K26transformed strains were grown aerobically at $30^{\circ} \mathrm{C}$ with constant shaking in SM medium. The CENPK2-1C strain and the novel derived strains (see Table 1) were grown aerobically at $30{ }^{\circ} \mathrm{C}$ with constant shaking in SM medium. Ethanol, glycerol, galactose or glucose ( $2 \%$ each) were used as carbon sources. The solid medium (YEP or SM) contained $18 \mathrm{~g} / \mathrm{L}$ agar.

\subsection{Preparation of Cellular Extracts}

Cells grown up to the early exponential phase $(5 \mathrm{~h})$ were harvested by centrifugation $(8000 \times g$ for $5 \mathrm{~min})$, washed with sterile water, resuspended in $250 \mu \mathrm{L}$ of lysis buffer (10 mM Tris- $\mathrm{HCl}$, pH 7.6, 1 mM EDTA, 1 mM dithiothreitol, $0.2 \mathrm{mM}$ phenylmethanesulfonylfluoride (PMSF), supplemented with one tablet of Roche protease inhibitor cocktail every $10 \mathrm{~mL}$ of lysis buffer), and vortexed with glass beads for $10 \mathrm{~min}$ at $4{ }^{\circ} \mathrm{C}$. The supernatant was removed and centrifuged at $3000 \times g$ for 5 min to remove cell debris.

\subsection{Preparation of Spheroplasts, Cytoplasm, Mitochondria, and Submitochondrial Fractions}

Spheroplasts were prepared using Zymolyase. Mitochondria and cytoplasm were isolated from spheroplasts as described in [23,40]. Mitochondria, ruptured by osmotic shock, were centrifuged at $20,000 \times g$ for $30 \mathrm{~min}$ to separate the mitochondrial soluble fraction and the mitochondrial membrane-enriched fraction.

\subsection{Western Blotting}

Protein from subcellular fractions or from cellular extracts were separated by SDSPAGE and transferred onto a PVDF membrane as in [42]. The immobilized proteins were incubated with either a monoclonal antibody against the STREP-tag raised in mouse $(\alpha$-STREP) to detect the recombinant Fad1p or a polyclonal $\alpha$-FADS antiserum (2000-fold dilution) raised in rabbit to detect Fad1p [29]. Immuno-reactive materials were visualized with the aid of a secondary anti-rabbit or anti-mouse IgG antibody conjugated with peroxidase. PVDF membranes were also probed with monoclonal $\alpha$-ACTIN antibody $(10,000$-fold dilution, raised in mouse), to reveal yeast actin (Act1p).

\subsection{RNA Isolation}

The RNeasy Midi Kit was used to extract total RNA from WT cells grown up to early exponential phase. Total RNA concentration was quantified by monitoring absorbance to $260 \mathrm{~nm}\left(\mathrm{OD}_{260 \mathrm{~nm}}\right)$, RNA integrity was verified by formaldehyde agarose gel electrophoresis and its purity was evaluated by measuring the $\mathrm{OD}_{260 \mathrm{~nm}} / \mathrm{OD}_{280 \mathrm{~nm}}$ ratio.

\subsection{3'RACE Analysis}

$3^{\prime}$ RACE analysis was performed on poly $(\mathrm{A})^{+}$RNA obtained from $75 \mu \mathrm{g}$ of total RNA using the Dynabeads mRNA Purification kit, according to the manufacturer's instructions. The purified poly $(\mathrm{A})^{+}$RNA was reverse-transcribed using the Enhanced AMV Reverse Transcriptase Kit and the oligo(dT)-anchor primer [oligo(dT)-AP], according to the manufacturer's instructions. The cDNA pool was diluted 10-fold and these were used 
as a template $(2.5 \mu \mathrm{L})$ for PCR reactions using a gene-specific primer and the AP primer. The specificity of the first round PCR-amplified fragment was proved by performing a semi-nested PCR. The sequence of primers, used in this study, are reported in Table 2. The $3^{\prime}$ RACE products were separated by $2 \%$ agarose gels. The fragments obtained with the first round PCR were purified from preparative agarose gel by using the Wizard SV Gel and PCR Clean-up system and then sequenced.

Table 2. Primers used in this study.

\begin{tabular}{|c|c|c|}
\hline Gene & Primer & Sequence \\
\hline \multirow{5}{*}{ FAD1 } & FAD1A.for & 5'-ATCGGCGGAATTAACAACTCA-3' \\
\hline & FAD1A.rev & 5'-TTGCCAAATGCATGAATGATTT-3' \\
\hline & FAD1B.for & 5'-GCCTAGCGGC GTGATAGTTAA-3' \\
\hline & FAD1B.rev & $5^{\prime}$-TGCTGGCTTAGTAACGGAATTG-3' \\
\hline & FAD1C.for & 5'-CATTTGGCAAGGACGCAGAA-3' \\
\hline \multirow{2}{*}{ SDH1 } & SDH1.for & 5'-GCCAATTCCTTGTTGGATCTTG-3' \\
\hline & SDH1.rev & 5'-TGGCAACCCAGGCTGTAAAG-3' \\
\hline \multirow{4}{*}{ ACT1 } & ACT1.for & 5'-TTCCATCCAAGCCGTTTTGT-3' \\
\hline & ACT1.rev & 5'-GGCGTGAGGTAGAGAGAAACCA-3' \\
\hline & Oligo(dT)-AP & $5^{\prime}$-GACCACGCGTATCGATGTCGAC $(\mathrm{T})_{16} \mathrm{~V}-3^{\prime}$ \\
\hline & AP.rev & 5'-GACCACGCGTATCGATGTCGAC-3' \\
\hline
\end{tabular}

\subsection{Semiquantitative RT-PCR Assay}

Semiquantitative RT-PCR assay was performed on $200 \mathrm{ng}$ of total RNA that was reverse-transcribed using the Enhanced AMV Reverse Transcriptase Kit. The cDNA pool was diluted 10-fold and $1 \mu \mathrm{L}$ was used as a template in PCR-amplification using genespecific primers (Table 2). Amplification conditions were as follows: $94{ }^{\circ} \mathrm{C}$ for $2 \mathrm{~min}$, then 25 cycles of $94^{\circ} \mathrm{C}$ for $15 \mathrm{~s}, 60^{\circ} \mathrm{C}$ for $30 \mathrm{~s}$, and $68^{\circ} \mathrm{C}$ for $1 \mathrm{~min}$. For each sample, ACT1 mRNA was used as an internal control. SDH1 mRNA was used as a control of inducible expression under nonfermentable carbon source growth conditions.

\subsection{Other Assays}

Fumarase (FUM), succinate dehydrogenase (SDH) and phosphoglucoisomerase (PGI) activities were spectrophotometrically measured as in $[40,42,44]$. Protein concentration was assayed according to Bradford [45], using bovine serum albumin as the standard.

\section{Results}

\subsection{Mitochondrial Localization of Recombinant Fad1p}

Our previous results based on functional approaches showed that, besides in the cytosol, FAD synthesizing activity can be specifically revealed in mitochondria from S. cerevisiae $[40,46]$. This result was somewhat surprising since a single gene, named FAD1, was reported as coding for a sole cytosolic FADS [16]. FAD1 gene, as normally occurs in yeasts, has no introns; thus, different transcripts generated by alternative splicing are not expected. Consistently, a single transcript is reported in the Ensemble database (http: / / www.ensembl.org/index.html, accessed on 13 September 2021) from which a single translation product, Fad1p, is predictable with NCBI tool ORF finder (www.ncbi.nlm. nih.gov / orffinder, accessed on 13 September 2021). No mitochondrial-targeting peptide could be found in this product using several prediction programs, such as iPSORT, MitoProt, TargetP and PSORT II. Concerning these aspects, the yeast FAD1 differs from the human FLAD1 gene, which generates alternatively spliced isoforms with different subcellular localizations $[29,30]$. Nevertheless, one of these isoforms, hFADS6, strongly resembles the yeast protein Fad1p, showing a high level of conservation for the PAPS reductase domain (Figure 1). 


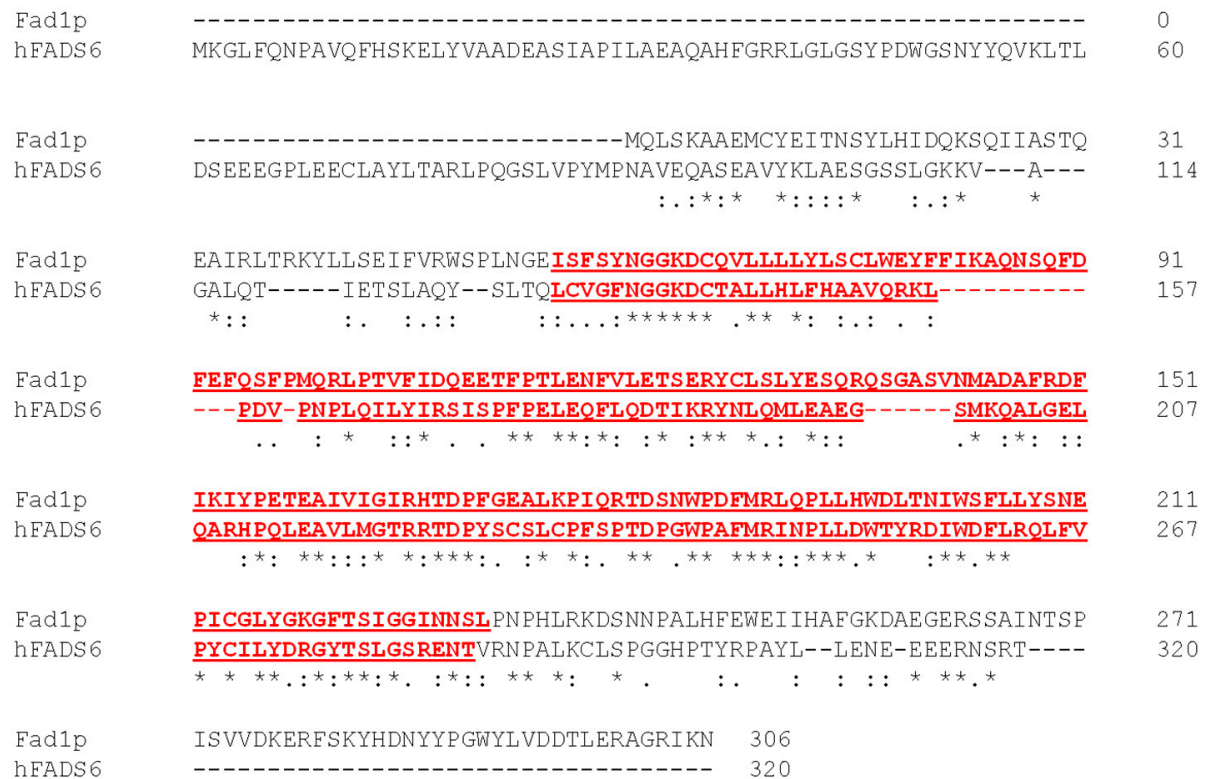

Figure 1. Alignment of FAD synthase sequences from yeast and humans. The alignment of yeast Fad1p with human FAD synthase isoform 6 (hFADS6) was performed by the Pairwise Sequence Alignment tool available at the EMBL-EBI website. The PAPS reductase domain (InterPro accession: IPR002500), present in both S. cerevisiae Fad1p (amino acids 55-231) and hFADS6 (amino acids 132-286), is underlined and colored in red. Asterisks depict identical residues in the same positions, whereas colons and periods indicate strongly and weakly similar residues, respectively.

To gain some insight into the cellular destination of Fad1p, we investigated the subcellular localization of the recombinant form of Fad1p carrying the STREP-tag at the C-terminus and overexpressed in the CENPK2-1C strain (Table 1). Therefore, subcellular fractions (spheroplasts, mitochondria and cytoplasm) were prepared from CENPK2$1 C^{\text {FAD1-STREP }}$ cells grown in ethanol up to early exponential growth phase and equal amounts of each fraction were analyzed by immunoblotting using the $\alpha$-STREP antibody (Figure 2a). Even though the recombinant Fad1p-STREP was enriched in the cytoplasmic fraction, an evident immuno-reactive band was observed in the mitochondrial fraction, suggesting a mitochondrial localization for the recombinant Fad1p-STREP. Interestingly, the recombinant Fad1p-STREP was immunodecorated at the same size both in mitochondria and in cytoplasm. When the STREP-tag was moved from the C- to the N-terminal end, the ability of the recombinant STREP-Fad1p to enter mitochondria was completely lost, accompanied by a significant enrichment in the cytoplasmic fraction (Figure S1).

To further prove the ability of the recombinant Fad1p to enter mitochondria, we placed Fad1p-STREP expression under the control of HXT7 promoter in the multicopy plasmid p426-HXT7-FAD1-STREP (Table 1) and used a different genetic strain, namely, K26. Subcellular fractions were prepared from K26 ${ }^{\text {FAD1-STREP }}$ cells grown in ethanol at the early exponential phase and analyzed by immunoblotting carried out with the $\alpha$-STREP (Figure $2 b$ ). The recombinant protein Fad1p-STREP was immunodecorated at the same size in both cytoplasm and mitochondria, where it was significantly enriched. When the K26 $6^{\text {FAD1-STREP }}$ cells were in the presence of the uncoupler carbonyl cyanide-ptrifluoromethoxy-phenylhydrazone (FCCP), the Fad1p-STREP import into mitochondria was prevented (Figure 2 b), as expected for a process depending on mitochondrial membrane potential [47]. This finding clearly indicates that the recombinant Fad1p is imported and localized to mitochondria. 
(a)

(b)
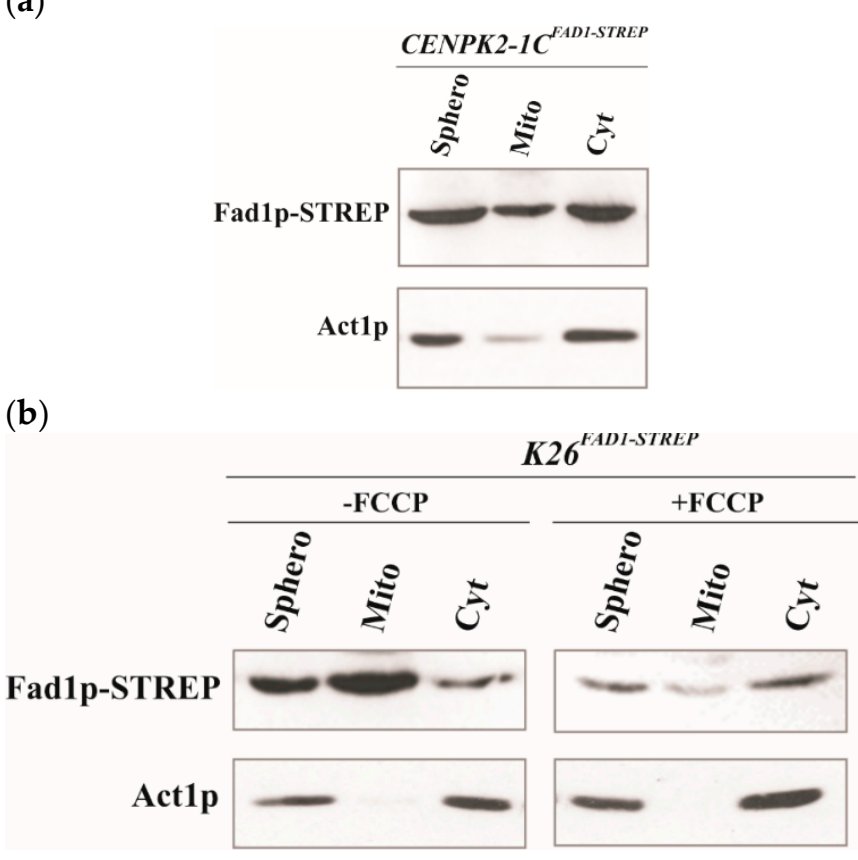

Figure 2. Mitochondrial localization of recombinant Fad1p. Spheroplasts (Sphero), mitochondria (Mito) and cytoplasm (Cyt) were prepared from CENPK2-1C (a) and K26 (b) cells transformed with the multicopy recombinant plasmid (Table 1). Both strains were grown up to the early exponential phase on ethanol. $\mathrm{K}_{2}{ }^{\mathrm{FAD1}}{ }^{\mathrm{STREP}}$ cells were incubated in the absence or presence of FCCP $(25 \mu \mathrm{M})$. Proteins $(0.1 \mathrm{mg})$ were separated by SDS-PAGE, transferred onto PVDF membrane and detected with either $\alpha$-STREP or $\alpha$-ACTIN antibodies.

\subsection{Natural Fad1p Exists in Mitochondria}

To ascertain whether the activity of FADS that we detected inside mitochondria is actually accountable to Fad1p, we analyzed the subcellular localization of natural Fad1p in cells grown either on nonfermentable (glycerol and ethanol) or fermentable (glucose and galactose) carbon sources up to the early exponential phase (5 h) (Figure 3a). A Fad1 1 band was detected in mitochondria prepared from glycerol-grown cells by using the $\alpha$-FADS antiserum. It should be noted that even though actin (Act1p) was used as a cytosolic marker [48], a minimal amount of Act1p was also found to be associated to the mitochondrial fraction in agreement with [49]. In ethanol, an even more intense band was detected in the mitochondrial fraction, whereas in glucose-grown cells, the mitochondrial Fad1p level was very low. Thus, the Fad1p content in mitochondria seems to depend on the carbon source. As a control, the dependence of the mitochondrial SDH specific activity on different carbon sources was analyzed (Figure 3b), thus verifying the expected glucose repression due to both transcriptional and post-transcriptional events [50,51]. It is noteworthy that in the mitochondria prepared from galactose-grown cells, no band was detected (Figure 3a), even though we observed a high (induced) level of SDH activity (Figure 3b), in agreement with the presence of mitochondria in cells cultured in galactose as the carbon source [52]. Differently from what was observed for the mitochondrial Fad1p, the cytosolic echoform did not appear to depend on the carbon source (Figure 3a). 
(a)

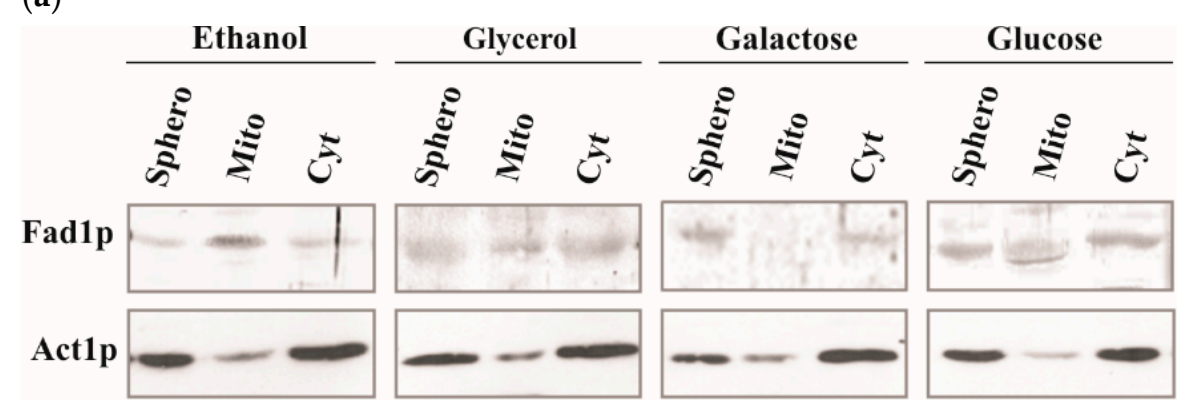

(b)

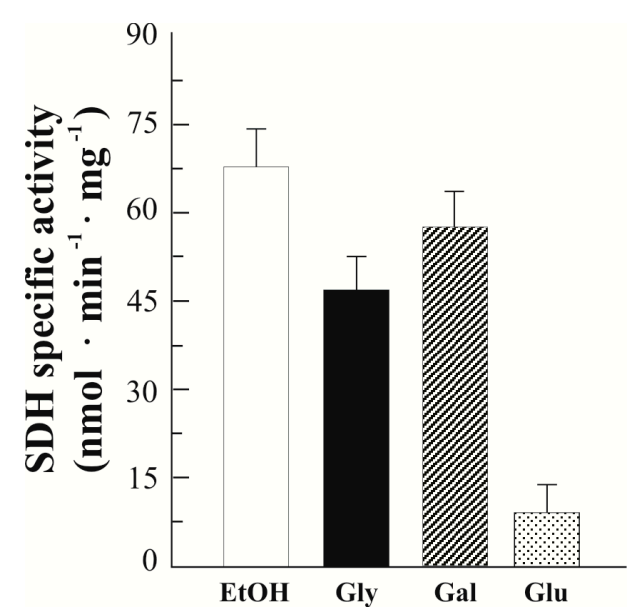

Figure 3. Subcellular distribution of Fad1p in different carbon sources. (a) Spheroplasts (Sphero), mitochondria (Mito) and cytoplasm (Cyt) were prepared from WT cells grown up to the early exponential phase at $30^{\circ} \mathrm{C}$ in YEP liquid medium supplemented with the indicated carbon sources ( $2 \%$ each). Proteins $(0.1 \mathrm{mg})$ were separated by SDS-PAGE, transferred onto PVDF membrane and detected with either $\alpha$-FADS or $\alpha$-ACTIN antibodies. (b) The carbon source dependence of the mitochondrial SDH-specific activity is reported as the means $( \pm \mathrm{SD})$ of two independent measurements.

Cellular sublocalization of Fad1p was also evaluated in K26 cells grown in glycerol up to the stationary phase (24 h), as in [40]. Cytoplasmic and mitochondrial fractions were prepared from spheroplasts and equal amounts of each fraction were used to reveal Fad1p by immunoblotting analysis (Figure S2). A faint $\alpha$-FADS immuno-reactive band was found in the cytoplasmic fraction. A much more evident band migrating at the same $\mathrm{Mr}$ was observed in total mitochondrial fraction, consistently enriched with respect to the spheroplast specific amount. A similar enrichment was observed for the fumarase (FUM) and succinate dehydrogenase (SDH), two mitochondrial markers (Figure S2, histogram). The absence of cytosolic contamination in mitochondria was demonstrated by the absence of phosphoglucoisomerase (PGI) activity, a marker of cytosolic fraction (Figure S2, histogram). Isolated mitochondria were further subfractionated in a membrane-enriched fraction $\left(\mathrm{M}_{\mathrm{fr}}\right)$ and in a soluble fraction $\left(\mathrm{S}_{\mathrm{fr}}\right)$. The Fad1p band was clearly detectable in both submitochondrial fractions, whose purity was confirmed by measuring the inner membrane marker SDH and the matrix marker FUM enzymatic activities (Figure S2, histogram).

Overall, on a molecular basis, these results support our previous functional data, proving that Fad1p exists in yeast mitochondria. Since no difference in size was observed between cytoplasmic and mitochondrial Fad1p, we postulated that the FAD1 gene might generate two identical echoforms, destined to two distinct subcellular localizations. 


\subsection{Detection of Two FAD1 mRNAs with Different 3'UTR and Their Carbon Source Dependence Profile}

In order to unravel the mechanism responsible for the subcellular destination of Fad1p, we considered a series of indications derived from the literature, which proposes a role for cis-acting $3^{\prime}$ UTR elements in targeting transcripts to mitochondria [53,54], and from a genome-wide analysis, which suggests a high probability for FAD1 mRNA to be located on mitochondria-bound polysomes [54]; hence, the protein would be imported while being translated in a co-translational process [55-57]. Therefore, we hypothesized that important information for Fad1p localization could reside in the $3^{\prime}$ UTR of FAD1 mRNA. Since no information was available, a combination of bioinformatic analyses and experimental procedures were carried out to gain knowledge about this untranslated region.

Firstly, we searched for putative polyadenylation sites (PASs), despite their complexity [58,59], and found two canonical signals (ATTAAA) in the $1 \mathrm{kbp}$ region downstream of FAD1 ORF using DNAFSMiner [60]. The proximal one was placed 50 nucleotides after the stop codon and the distal one was placed 339 nucleotides after the stop codon. The bioinformatic tool also predicted other different PASs with similar scores, namely, AATAAA and TATCAA (Figure S3). These predictions suggested that FAD1 mRNA may be present in different forms, whose length depends on the alternative use of distinct PASs in the transcript 3'UTR.

To test this hypothesis, $3^{\prime}$ RACE experiments were performed on a template cDNA obtained from purified poly(A) ${ }^{+}$RNA prepared from WT cells grown at the early exponential phase on glucose as a carbon source and the gene-specific primers (Table 2; Figure 4a). When the primers FAD1A.for and AP were used, a single amplified product of about $400 \mathrm{bp}$ was obtained (Figure $4 \mathrm{~b}$, lane 1 ). The specificity of the $400 \mathrm{bp}$ product was verified by a semi-nested PCR using the gene-specific primer FAD1C.for located 91 nucleotides downstream of FAD1A.for. The amplified product was obtained at the expected size, which is about $300 \mathrm{bp}$ (Figure $4 \mathrm{~b}$, lane 2). The $400 \mathrm{bp}$ fragment was sequenced, revealing the existence of FAD1 transcript with a 3'UTR of 128 nucleotides (Figure S3). To search for the existence of a longer $3^{\prime} \mathrm{UTR}$ region of FAD1 mRNA, a PCR was performed using the primers FAD1C.for and FAD1B.rev, the last being located downstream of the end of the $3^{\prime}$ UTR previously identified (Figure 4 b); in this case, a product of about 450 nucleotides was obtained (Figure 4b, lane 3), indicating the existence of a longer FAD1 mRNA. To define the entire length of the $3^{\prime} \mathrm{UTR}$ of this transcript, a PCR reaction was performed using the primers FAD1B.for and AP, obtaining a product of $550 \mathrm{bp}$ (Figure $4 \mathrm{~b}$, lanes 4 and 5). Its specificity was proved by a semi-nested PCR with the primers FAD1B.for and FAD1B.rev, which gave rise to a fragment of about $100 \mathrm{bp}$, as expected (Figure $4 \mathrm{~b}$, lane 6). The $550 \mathrm{bp}$ product was sequenced, showing the existence of an additional FAD1 mRNA with a longer $3^{\prime}$ UTR region of $759 \mathrm{bp}$ (Figure S2). Similar results were obtained when the analysis was performed using cDNA as a template, obtained starting from purified poly $(\mathrm{A})^{+}$RNA prepared from WT cells grown on glycerol (Figure S4). Thus, FAD1 generates (at least) two FAD1 mRNAs with different $3^{\prime}$ UTR lengths. Based on the different length of the $3^{\prime} U T R$, we named them 'short FAD1 mRNA' and 'long FAD1 mRNA', respectively.

To understand whether or not the length of $3^{\prime}$ UTR is responsible for the fate of Fad1p echoforms, the carbon source dependence of the FAD1 transcript levels was investigated. To this purpose, total RNA was extracted from WT cells grown at the early exponential phase on different carbon sources, and the amount of FAD1 transcripts was evaluated by semiquantitative RT-PCR, with ACT1 mRNA used as an internal control, essentially as in [42]. The long FAD1 mRNA was amplified using the primer pair FAD1A.for and FAD1B.rev, whereas the total FAD1 mRNA (short + long) was amplified using the primer pair FAD1A.for and FAD1A.rev (Figure S5). The RT-PCR product (540 bp) relative to the long FAD1 mRNA complemented the $3^{\prime} \mathrm{RACE}$ data, confirming the presence of a longer transcript. The relative amount of total FAD1 mRNA did not depend on the carbon source, whereas a carbon source dependence was observed for the long FAD1 mRNA: its amount was higher in ethanol grown cells, reduced in cells grown on glucose and almost absent in galactose-grown cells. As a control, the expression pattern of SDH1 mRNA was analyzed; it 
was repressed by glucose, but not by galactose (Figure S5), in agreement with SDH activity reported here (Figure 3, histogram) and in literature [50].

(a)

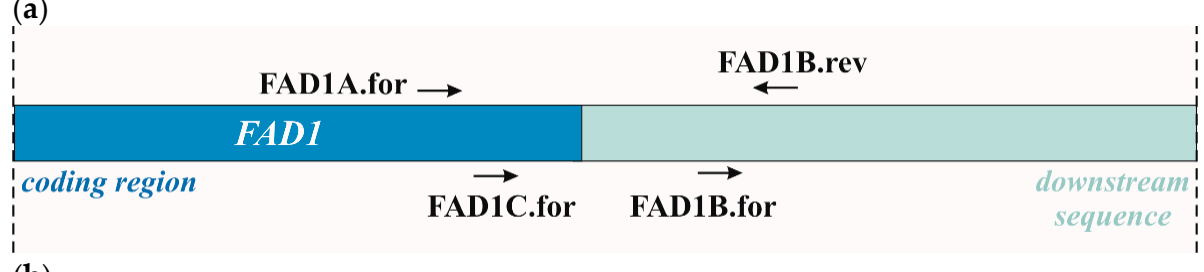

(b)
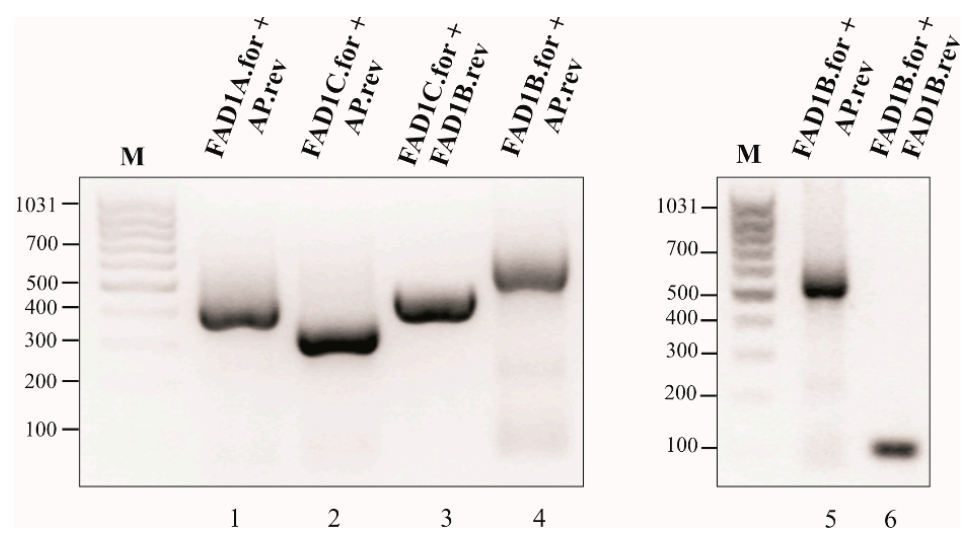

Figure 4. Characterization of FAD1 mRNA $3^{\prime} \mathrm{UTR}$ by $3^{\prime} \mathrm{RACE}$ analysis. (a) FAD1 coding region and $1 \mathrm{kbp}$ downstream region are schematized. Arrows designate the position and direction of gene-specific primers used for $3^{\prime}$ RACE. (b) The experiment was carried out on a poly $(\mathrm{A})^{+} \mathrm{RNA}$ prepared from WT cells grown up to the early exponential phase at $30^{\circ} \mathrm{C}$ on glucose. PCR products were separated by a $2 \%$ agarose gel. Fragments in lanes 1 and 4 were gel-extracted, purified and sequenced (Figure S3). On the left side of each gel, band sizes (bp) of the marker [M, MassRuler Low Range DNA Ladder, ThermoFisher Scientific (Waltham, MA, USA)] are indicated.

\subsection{A Mitochondrial Localization Motif in FAD1 3'UTRs}

To further confirm that Fad1p localization mechanism might be influenced at the mRNA level, we searched for cis-acting elements that could be responsible for targeting FAD1 mRNA to the outer mitochondrial membrane. Sequence inspection revealed the existence of a putative cis-acting motif TGTATATACA containing the consensus mitochondrial localization motif M1 (TGTA(a/c/t/)ATA), as defined in [61], and resembling the motif 6 (WTATWTACADG) reported as a mitochondrial downstream motif [62]. This element was located about 90 nucleotides downstream the FAD1 ORF stop codon; therefore, it was present in both FAD1 transcripts. The same motif (or similar sequences) was not found in either the upstream FAD1 ORF region or the FAD1 ORF.

The $1 \mathrm{kbp}$ genomic downstream region FAD1 ORF contains, on the opposite strand the MRP10 gene, encoding a mitochondrial ribosomal protein of $10.7 \mathrm{kDa}[63,64]$. Mrp10p lacks a mitochondrial-targeting sequence (as revealed by bioinformatic analysis); however, the identified M1 mitochondrial localization motif is present in its $3^{\prime} \mathrm{UTR}$, as revealed by the Shalgi's database [61]. This motif is placed 56 nucleotides downstream of the MRP10 ORF stop codon. It should be noted that the M1 motif in 3'UTR of FAD1 and MRP10 is a palindromic sequence that could be read on both DNA strands (Figure 5). This property implies a rather nontrivial extension of the M1 motif and allows the same region to play the role of mitochondrial localization motif for both the MRP10 and the FAD1 transcripts. 


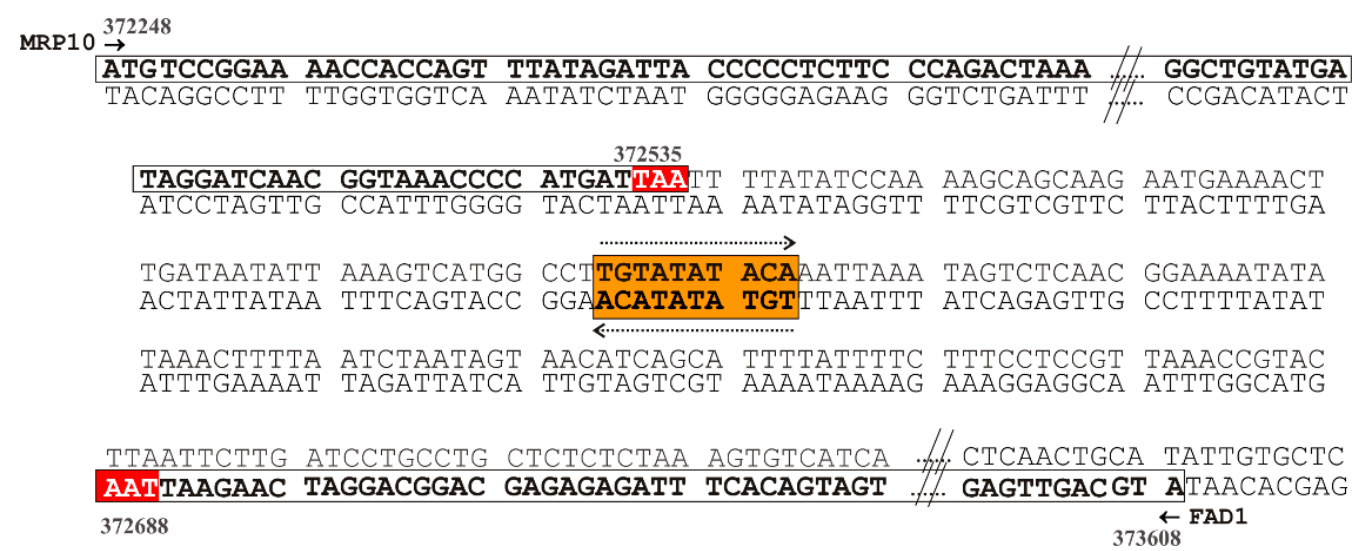

Figure 5. The cis-acting motif M1 in the $3^{\prime} \mathrm{UTR}$ of FAD1 transcripts. Schematic representation of the partial sequence of the S. cerevisiae genomic region comprised between nucleotides 372248 and 373617 (chromosome IV). The white boxes indicate FAD1 ORF on the Crick strand and MRP10 ORF on the Watson strand; the orange box indicates the mitochondrial localization motif M1, placed about 87 and 55 nucleotides downstream of the stop codon (TAA, highlighted in red) of FAD1 and MRP10 ORFs, respectively. The dotted arrows highlight the bidirectionality of the M1 palindromic sequence.

\section{Discussion}

Experiments reported in this paper point out the issue of the origin of mitochondrial FAD in S. cerevisiae mitochondria, strictly related with the problem of the identity and of the subcellular localization of the FAD forming enzyme, FADS. Immunoblotting experiments reported here reveal the presence of an $\alpha$-FADS immuno-reactive band in mitochondria, showing the same $\mathrm{Mr}$ of that found in the spheroplasts and cytoplasm. This is in line with the absence of a putative cleavable presequence in Fad1p, the sole peptide generated by FAD1 gene. Thus, these results prove, on a molecular basis, Fad1p localization to yeast mitochondria and support the absence of a cleavable mitochondrial signal peptide in Fad1p.

It is well-documented that in eukaryotic cells, a protein can be located to two different subcellular compartments; this dual localization results in different echoforms-that is, proteins with identical or nearly identical amino acid sequences distinctly placed in the cell [65-67]. This is an important and frequent phenomenon; in fact, more than one third of the yeast mitochondrial proteome seems to be dual localized $[68,69]$. It has also become evident that dual localization can be regulated, induced and rebalanced in response to either cellular signaling or changing extracellular conditions. Different dual-targeting mechanisms of mitochondrial proteins have been described or suggested, and, in some case, they seem to be tightly regulated in time, location and function [65]. Our results demonstrate that FAD1 generates two echoforms.

Analyzing the dependence of the Fad1p levels on fermentable and nonfermentable carbon sources (Figure 3), we verified that the amount of Fad1p in mitochondria, but not in the cytoplasm, depends on the carbon source being higher in ethanol and glycerol than in the fermentable glucose. Interestingly, mitochondrial Fad1p almost disappeared in galactose-grown cells. This finding may settle the discrepancy between results from our (see Introduction) and other laboratories [32,39] about the existence of mitochondrial FADS and, consequently, about the direction of FAD transport via the inner mitochondrial membrane translocator Flx1p. The absence of mitochondrial Fad1p, observed in galactose-grown cells, implies that in this condition FAD must be transported from cytosol to mitochondria via Flx1p (Figure 3 [32,39]). Vice versa, in a nonfermentable carbon source and in glucose, in the presence of mitochondrial Fad1p, Flx1p is expected to mediate FAD efflux from mitochondria to cytosol acting as a regulator of apo-flavoprotein biogenesis [40,42].

Using yeast strains overexpressing a recombinant form of Fad1p, the dual location of natural Fad1p was confirmed. Our data demonstrate that Fad1p is, per se, able to enter mitochondria, despite the absence of a canonical mitochondrial-targeting sequence. A 
"mitochondrial destination" message should be localized at the N-terminal end, since Fad1p loses its ability when the STREP-tag is moved from the C- to the N-terminal end (Figure S1). Presumably, the $\alpha 1$-helix in the first twenty amino acids at the $\mathrm{N}$-terminal end, as well as the contiguous $\alpha 2$-helix, indeed have amphipathic characteristics, with the basic residues exposed to the solvent from the same side of the central axis, as revealed by the crystal structure solved at $1.9 \AA$ resolution (PDB entry: $2 \mathrm{wsi}$ ) [20]. This would be in agreement with the involvement of this protein moiety in the import process. Alternatively, another putative noncanonical/weak mitochondrial-targeting sequence [70] could be implicated in the mitochondrial destination of Fad1p.

We also observed that in galactose-grown cells, the recombinant Fad1p-STREP entered mitochondria per se [71], behaving differently from the natural Fad1p that was unable to enter mitochondria. All together, these data suggest the existence of a fine mechanism regulating the localization of the natural Fad1p, presumably at the transcript level and dependent on the carbon source. It is well-established that intracellular localization of mRNA has a significant impact on the efficiency of its translation and, presumably, determines its response to changing metabolic conditions or cellular stress [72].

Our attention was focused on the 3'UTR region of FAD1 mRNA. Since no information was available on this region, we carried out a $3^{\prime}$ RACE analysis and found the existence of (at least) two FAD1 mRNAs with different $3^{\prime}$ UTR lengths (Figure 4). This finding could be relevant for Fad1p cell biology, since it is well-known that $3^{\prime} \mathrm{UTR}$ regulates multiple aspects of mRNA metabolism, including subcellular localization, translation efficiency and stability, in cooperation with different RNA binding proteins [73]. A mechanism that could have a role in generating different transcripts with specific subcellular localizations and/or functions might be alternative polyadenylation [74,75]. We predicted different canonical and noncanonical putative PASs localized in the first $1 \mathrm{kbp}$ downstream of FAD1 ORF. Whether or not these PASs are actually active and responsible for the generation of the two FAD1 transcripts are matter of ongoing investigation in our laboratory.

Searching for possible cis-acting motifs responsible for the peripheral mitochondrial localization of $F A D 1$ transcripts, we revealed the existence of the mitochondrial localization motif M1, placed 87 nucleotides downstream the FAD1 ORF stop codon (Figure 5). The same motif has been identified within a set of genes encoding mitochondrial proteins, whose mRNAs are translated by polyribosomes attached to the cytosolic side of the outer mitochondrial membrane [76]. This motif is present in both FAD1 transcripts, which might localize close to the mitochondrial outer membrane. Intriguingly, this finding is in agreement with a value of mitochondrial localization of mRNA (MLR) for FAD1 equal to 87 [54]. This value is similar to the MLR values measured for other mRNAs, whose products have been demonstrated to be internalized into mitochondria (i.e., 87.8 for SDH1 transcript), thus indicating that Fad1p translation has a high probability to occur on the mitochondrial outer membrane. Recently, it has been reported that mRNAs that initiate translation away from mitochondria experience a significant drop in mobility toward the outer mitochondrial membrane and tend to remain there [77]. The M1 motif is a candidate binding site of the RNA binding protein Puf3p [78], localized on the cytosolic side of the outer mitochondrial membrane, where it interacts with some components of the mitochondrial protein import machinery $[57,79]$. Besides its role in mRNA targeting to mitochondria, Puf3p controls mRNA stability and translation efficiency according to growth conditions and in response to oxidative stress [80-82]. The identified palindromic M1 motif is shared by the $3^{\prime} \mathrm{UTR}$ of FAD1 transcripts and the $3^{\prime}$ downstream region of MRP10 gene, which is transcribed in the opposite direction with respect to FAD1 gene. Since an interaction between the M1 of MRP10 mRNA and Puf3p has been proven [83,84], an involvement of Puf3p in mitochondrial localization of Fad1p could be expected. By analyzing the carbon source dependence profile of FAD1 transcripts (Figure S3), we found that the long transcript is expressed in ethanol and in glycerol at a higher level than in glucose; it is almost absent in galactose. The comparison between this profile and mitochondrial Fad1p levels (Figure 3) shows that the carbon source dependence of the long 
FAD1 mRNA level strictly parallels the carbon source dependence of the mitochondrial Fad1p level. This observation suggests that the long FAD1 mRNA might be responsible for the generation of Fad1p mitochondrial echoform. Therefore, although the M1 motif is present in both the short and long FAD1 transcripts, we propose that the different length of the $3^{\prime}$ UTRs could be responsible for the distinct subcellular destinations of Fad1p. This diverse destination could be explained by a differential Puf3p-M1 interaction caused by the exposure of M1 motif in different RNA contexts. In this scenario, the secondary structure of the two 3'UTRs may be causative of the selective interaction with Puf3p. Moreover, the recruitment of additional RNA binding proteins, presumably involved in mRNA decay or Puf3p interaction with mitochondrial import machinery [85], could also be affected by $3^{\prime}$ UTR length and structure. Therefore, Puf3p might regulate the dynamic balance between translation efficiency, protein folding and import rate, thus establishing whether Fad1p may be released in the cytosol or imported into mitochondria [81]. Additionally, it has been shown that cytosolic ribosomes have the ability to 'sense' features relative to nascent polypeptide chains; between those features, the sequence and structure of $3^{\prime} U T R$ mRNAs can influence the polypeptide synthesis rate, modulating translation accordingly $[76,86]$. It is noteworthy that the M1 motif was not included in the constructs used for the expression of recombinant Fad1p. Nonetheless, the protein was capable, per se, of localizing to mitochondria in the presence of the mitochondrial membrane potential (Figure 2; [71]). Therefore, the M1 sequence would serve to fine-tune the cellular localization of Fad1p echoforms in various metabolic conditions, such as different carbon sources.

Our hypothesis is summarized in Figure 6. We speculate that, when Puf3p is bound to the M1 motif present in the long $3^{\prime} U T R$ context (panel a), Fad1p synthesis efficiency and/or folding rate are slowed down, allowing the co-translational import to proceed and generate the Fad1p mitochondrial echoform. Vice versa, when Puf3p interacts with the M1 in the short $3^{\prime}$ UTR (panel b), a higher translation rate might cause a premature folding, thus favoring the cytosolic destination of Fad1p.

(a)

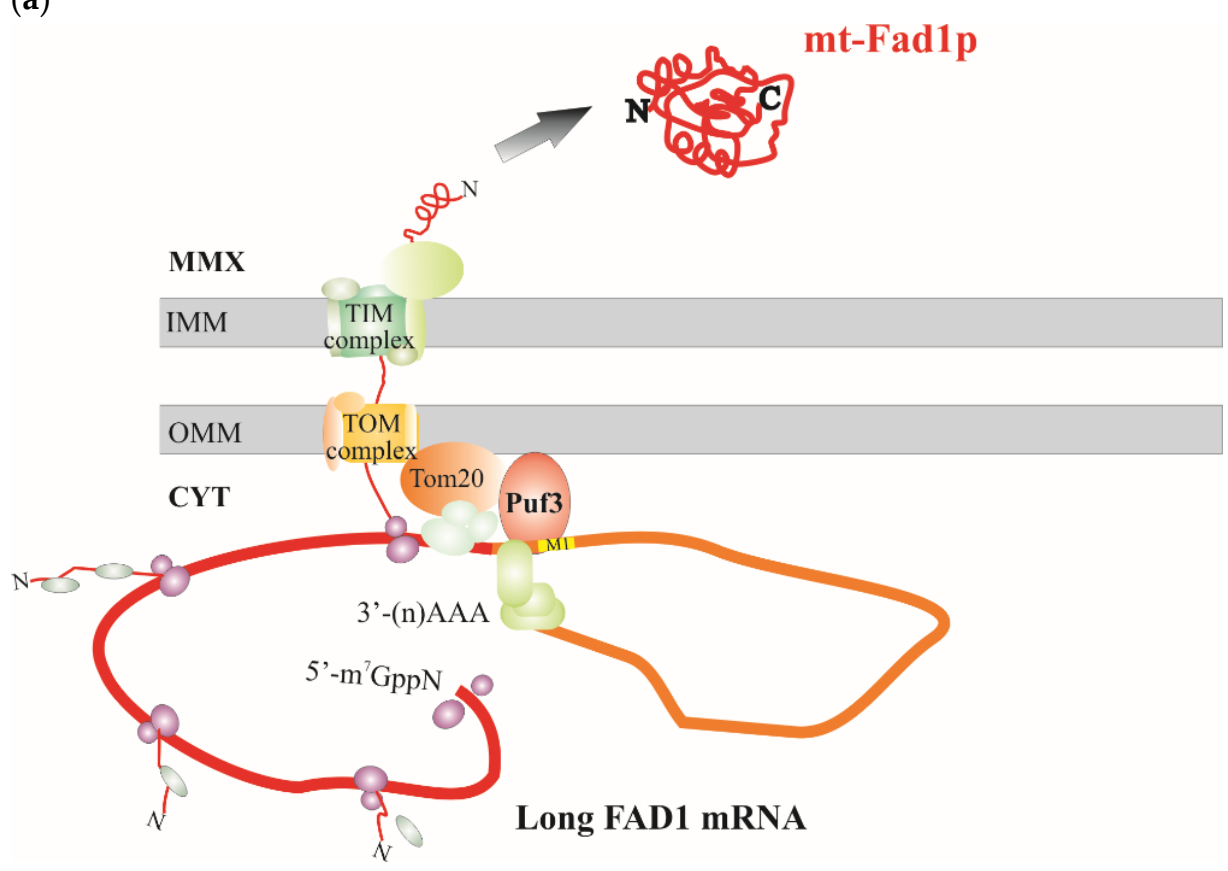

Figure 6. Cont. 
(b)

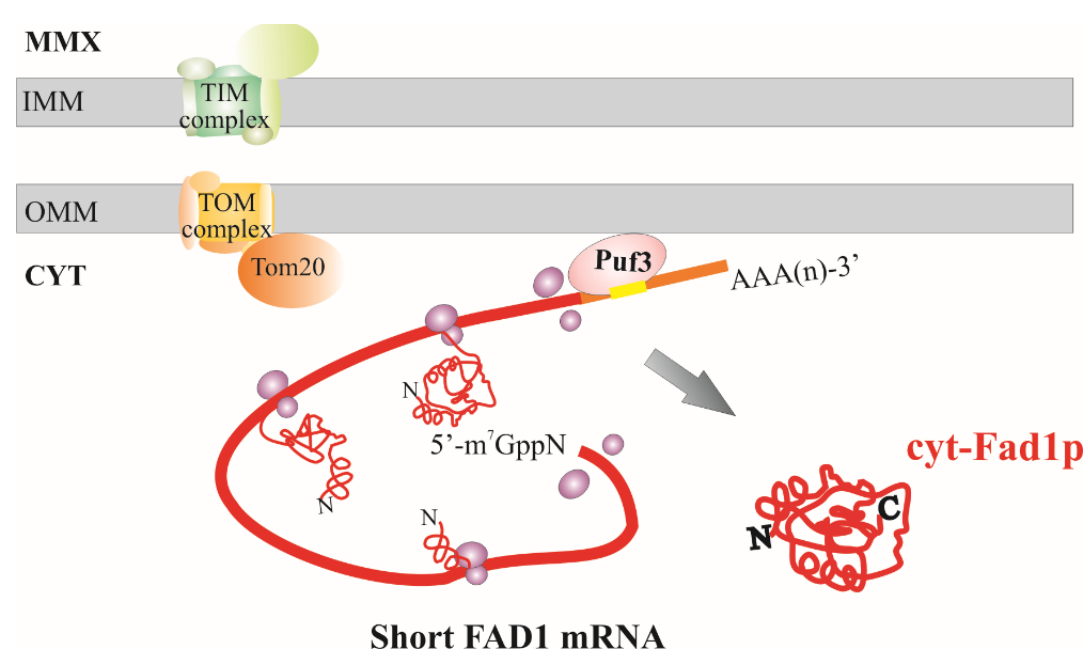

Figure 6. Model depicting the dual location of Fad1p. The cartoon shows a possible role of Puf3p in the different destination of Fad1p echoforms. (a) Puf3p binds to the long FAD1 mRNA and drives the nascent polypeptide in the mitochondrial matrix (MMX) via TOM-TIM complexes before the fully translated protein starts to fold. (b) Puf3p binds to the short FAD1 mRNA. As translation is presumably not sufficiently slowed down, premature and rapid folding of the nascent polypeptide in the cytosol (CYT) prevents Fad1p import across mitochondrial membranes (OMM-outer mitochondrial membrane; IMM—inner mitochondrial membrane).

Supplementary Materials: The following are available online at https: / www.mdpi.com/article/ 10.3390/life11090967/s1. Figure S1: Sublocalization of recombinant STREP-Fad1p. Figure S2: Endogenous Fad1p mitochondrial localization in WT cells grown up to the stationary phase $(24 \mathrm{~h})$ on glycerol. Figure S3: FAD1 ORF and its $1 \mathrm{kbp}$ downstream region. Figure S4: 3'RACE analysis carried out on cells grown on glycerol (early exponential phase, $30^{\circ} \mathrm{C}$ ). Figure S5: Carbon source dependence of FAD1 transcripts.

Author Contributions: Conceptualization, M.B., M.R., M.C., and E.B.; methodology, E.B. and M.R.; formal analysis, M.C., P.L., and F.B.; investigation, F.B., M.O., T.A.G., M.T., and P.L.; resources, E.B., M.R., and M.B.; writing-original draft preparation, M.B. and T.A.G.; writing-review and editing, M.R., F.B., and M.T.; supervision, M.C. and M.R.; project administration, M.B., M.O., M.R., and M.C.; funding acquisition, M.B. All authors have read and agreed to the published version of the manuscript.

Funding: This work was supported by grants from MIUR PON-ricerca e competitività 2007-2013 (project PON01_00937: "Modelli sperimentali biotecnologici integrati per lo sviluppo e la selezione di molecole di interesse per la salute dell'uomo") and from Università degli Studi di Bari "Aldo Moro" (Progetti Competitivi "Effetto di mutazioni di FLAD1 e di alterazioni dell'omeostasi delle flavine sullo stato redox e sulla biogenesi mitocondriale: uno studio integrato su fibroblasti umani") to M.B.

Institutional Review Board Statement: Not applicable.

Informed Consent Statement: Not applicable.

Data Availability Statement: Not applicable.

Acknowledgments: The helpful collaboration of Emilia Dipalo, who participated as a student in the early stages of this work, is gratefully acknowledged.

Conflicts of Interest: The authors declare no conflict of interest. 


\section{References}

1. Tolomeo, M.; Nisco, A.; Leone, P.; Barile, M. Development of Novel Experimental Models to Study Flavoproteome Alterations in Human Neuromuscular Diseases: The Effect of Rf Therapy. Int. J. Mol. Sci. 2020, 21, 5310. [CrossRef]

2. Joosten, V.; Van Berkel, W.J. Flavoenzymes. Curr. Opin. Chem. Biol. 2007, 11, 195-202. [CrossRef] [PubMed]

3. Macheroux, P.; Kappes, B.; Ealick, S.E. Flavogenomics-A genomic and structural view of flavin-dependent proteins. FEBS J. 2011, 278, 2625-2634. [CrossRef] [PubMed]

4. Barile, M.; Giancaspero, T.A.; Leone, P.; Galluccio, M.; Indiveri, C. Riboflavin transport and metabolism in humans. J. Inherit. Metab. Dis. 2016, 39, 545-557. [CrossRef]

5. Pimentel, C.; Batista-Nascimento, L.; Rodrigues-Pousada, C.; Menezes, R.A. Oxidative stress in Alzheimer's and Parkinson's diseases: Insights from the yeast Saccharomyces cerevisiae. Oxidative Med. Cell. Longev. 2012, 2012, 132146. [CrossRef]

6. Botstein, D.; Fink, G.R. Yeast: An experimental organism for 21st Century biology. Genetics 2011, 189, 695-704. [CrossRef]

7. Tenreiro, S.; Outeiro, T.F. Simple is good: Yeast models of neurodegeneration. FEMS Yeast Res. 2010, 10, 970-979. [CrossRef] [PubMed]

8. Bastow, E.L.; Gourlay, C.W.; Tuite, M.F. Using yeast models to probe the molecular basis of amyotrophic lateral sclerosis. Biochem. Soc. Trans. 2012, 39, 1482-1487. [CrossRef] [PubMed]

9. Reihl, P.; Stolz, J. The monocarboxylate transporter homolog Mch5p catalyzes riboflavin (vitamin B2) uptake in Saccharomyces cerevisiae. J. Biol. Chem. 2005, 280, 39809-39817. [CrossRef] [PubMed]

10. Moriyama, Y. Riboflavin transporter is finally identified. J. Biochem. 2011, 150, 341-343. [CrossRef]

11. Yonezawa, A.; Inui, K. Novel riboflavin transporter family RFVT/SLC52: Identification, nomenclature, functional characterization and genetic diseases of RFVT/SLC52. Mol. Asp. Med. 2013, 34, 693-701. [CrossRef]

12. O'Callaghan, B.; Bosch, A.M.; Houlden, H. An update on the genetics, clinical presentation, and pathomechanisms of human riboflavin transporter deficiency. J. Inherit. Metab. Dis. 2019, 42, 598-607. [CrossRef]

13. Yruela, I.; Arilla-Luna, S.; Medina, M.; Contreras-Moreira, B. Evolutionary divergence of chloroplast FAD synthetase proteins. BMC Evol. Biol. 2010, 10, 311. [CrossRef]

14. Giancaspero, T.A.; Colella, M.; Brizio, C.; Difonzo, G.; Fiorino, G.M.; Leone, P.; Brandsch, R.; Bonomi, F.; Iametti, S.; Barile, M. Remaining challenges in cellular flavin cofactor homeostasis and flavoprotein biogenesis. Front. Chem. 2015, 3, 30. [CrossRef]

15. Santos, M.A.; Jimenez, A.; Revuelta, J.L. Molecular characterization of FMN1, the structural gene for the monofunctional flavokinase of Saccharomyces cerevisiae. J. Biol. Chem. 2000, 275, 28618-28624. [CrossRef]

16. Wu, M.; Repetto, B.; Glerum, D.M.; Tzagoloff, A. Cloning and characterization of FAD1, the structural gene for flavin adenine dinucleotide synthetase of Saccharomyces cerevisiae. Mol. Cell. Biol. 1995, 15, 264-271. [CrossRef]

17. Bauer, S.; Kemter, K.; Bacher, A.; Huber, R.; Fischer, M.; Steinbacher, S. Crystal structure of Schizosaccharomyces pombe riboflavin kinase reveals a novel ATP and riboflavin-binding fold. J. Mol. Biol. 2003, 326, 1463-1473. [CrossRef]

18. Karthikeyan, S.; Zhou, Q.; Mseeh, F.; Grishin, N.V.; Osterman, A.L.; Zhang, H. Crystal structure of human riboflavin kinase reveals a beta barrel fold and a novel active site arch. Structure 2003, 11, 265-273. [CrossRef]

19. Karthikeyan, S.; Zhou, Q.; Osterman, A.L.; Zhang, H. Ligand binding-induced conformational changes in riboflavin kinase: Structural basis for the ordered mechanism. Biochemistry 2003, 42, 12532-12538. [CrossRef] [PubMed]

20. Leulliot, N.; Blondeau, K.; Keller, J.; Ulryck, N.; Quevillon-Cheruel, S.; Van Tilbeurgh, H. Crystal structure of yeast FAD synthetase (Fad1) in complex with FAD. J. Mol. Biol. 2010, 398, 641-646. [CrossRef] [PubMed]

21. Brizio, C.; Galluccio, M.; Wait, R.; Torchetti, E.M.; Bafunno, V.; Accardi, R.; Gianazza, E.; Indiveri, C.; Barile, M. Over-expression in Escherichia coli and characterization of two recombinant isoforms of human FAD synthetase. Biochem. Biophys. Res. Commun. 2006, 344, 1008-1016. [CrossRef] [PubMed]

22. Leone, P.; Galluccio, M.; Brizio, C.; Barbiroli, A.; Iametti, S.; Indiveri, C.; Barile, M. The hidden side of the human FAD synthase 2. Int. J. Biol. Macromol. 2019, 138, 986-995. [CrossRef]

23. Giancaspero, T.A.; Locato, V.; Barile, M. A regulatory role of NAD redox status on flavin cofactor homeostasis in S. cerevisiae mitochondria. Oxidative Med. Cell. Longev. 2013, 2013, 612784. [CrossRef]

24. Vergani, L.; Barile, M.; Angelini, C.; Burlina, A.B.; Nijtmans, L.; Freda, M.P.; Brizio, C.; Zerbetto, E.; Dabbeni-Sala, F. Riboflavin therapy. Biochemical heterogeneity in two adult lipid storage myopathies. Brain A J. Neurol. 1999, 122 Pt 12, 2401-2411. [CrossRef]

25. Gianazza, E.; Vergani, L.; Wait, R.; Brizio, C.; Brambilla, D.; Begum, S.; Giancaspero, T.A.; Conserva, F.; Eberini, I.; Bufano, D.; et al. Coordinated and reversible reduction of enzymes involved in terminal oxidative metabolism in skeletal muscle mitochondria from a riboflavin-responsive, multiple acyl-CoA dehydrogenase deficiency patient. Electrophoresis 2006, 27, 1182-1198. [CrossRef] [PubMed]

26. Olsen, R.K.J.; Konarikova, E.; Giancaspero, T.A.; Mosegaard, S.; Boczonadi, V.; Matakovic, L.; Veauville-Merllie, A.; Terrile, C.; Schwarzmayr, T.; Haack, T.B.; et al. Riboflavin-Responsive and -Non-responsive Mutations in FAD Synthase Cause Multiple Acyl-CoA Dehydrogenase and Combined Respiratory-Chain Deficiency. Am. J. Hum. Genet. 2016, 98, 1130-1145. [CrossRef]

27. Gregersen, N.; Andresen, B.S.; Pedersen, C.B.; Olsen, R.K.; Corydon, T.J.; Bross, P. Mitochondrial fatty acid oxidation defectsremaining challenges. J. Inherit. Metab. Dis. 2008, 31, 643-657. [CrossRef]

28. Leone, P.; Galluccio, M.; Barbiroli, A.; Eberini, I.; Tolomeo, M.; Vrenna, F.; Gianazza, E.; Iametti, S.; Bonomi, F.; Indiveri, C.; et al. Bacterial Production, Characterization and Protein Modeling of a Novel Monofuctional Isoform of FAD Synthase in Humans: An Emergency Protein? Molecules 2018, 23, 116. [CrossRef] 
29. Torchetti, E.M.; Brizio, C.; Colella, M.; Galluccio, M.; Giancaspero, T.A.; Indiveri, C.; Roberti, M.; Barile, M. Mitochondrial localization of human FAD synthetase isoform 1. Mitochondrion 2010, 10, 263-273. [CrossRef] [PubMed]

30. Giancaspero, T.A.; Busco, G.; Panebianco, C.; Carmone, C.; Miccolis, A.; Liuzzi, G.M.; Colella, M.; Barile, M. FAD synthesis and degradation in the nucleus create a local flavin cofactor pool. J. Biol. Chem. 2013, 288, 29069-29080. [CrossRef]

31. Gudipati, V.; Koch, K.; Lienhart, W.D.; Macheroux, P. The flavoproteome of the yeast Saccharomyces cerevisiae. Biochim. Et Biophys. Acta 2014, 1844, 535-544. [CrossRef]

32. Hao, H.X.; Khalimonchuk, O.; Schraders, M.; Dephoure, N.; Bayley, J.P.; Kunst, H.; Devilee, P.; Cremers, C.W.; Schiffman, J.D.; Bentz, B.G.; et al. SDH5, a gene required for flavination of succinate dehydrogenase, is mutated in paraganglioma. Science 2009, 325, 1139-1142. [CrossRef] [PubMed]

33. Ghezzi, D.; Goffrini, P.; Uziel, G.; Horvath, R.; Klopstock, T.; Lochmuller, H.; D'Adamo, P.; Gasparini, P.; Strom, T.M.; Prokisch, H.; et al. SDHAF1, encoding a LYR complex-II specific assembly factor, is mutated in SDH-defective infantile leukoencephalopathy. Nat. Genet. 2009, 41, 654-656. [CrossRef]

34. Robinson, K.M.; Lemire, B.D. Covalent attachment of FAD to the yeast succinate dehydrogenase flavoprotein requires import into mitochondria, presequence removal, and folding. J. Biol. Chem. 1996, 271, 4055-4060. [CrossRef] [PubMed]

35. Kim, H.J.; Winge, D.R. Emerging concepts in the flavinylation of succinate dehydrogenase. Biochim. Biophys. Acta 2013, 1827, 627-636. [CrossRef] [PubMed]

36. Rutter, J.; Winge, D.R.; Schiffman, J.D. Succinate dehydrogenase-Assembly, regulation and role in human disease. Mitochondrion 2010, 10, 393-401. [CrossRef]

37. Schiff, M.; Veauville-Merllie, A.; Su, C.H.; Tzagoloff, A.; Rak, M.; Ogier de Baulny, H.; Boutron, A.; Smedts-Walters, H.; Romero, N.B.; Rigal, O.; et al. SLC25A32 Mutations and Riboflavin-Responsive Exercise Intolerance. N. Engl. J. Med. 2016, 374, 795-797. [CrossRef]

38. Hellebrekers, D.; Sallevelt, S.; Theunissen, T.E.J.; Hendrickx, A.T.M.; Gottschalk, R.W.; Hoeijmakers, J.G.J.; Habets, D.D.; Bierau, J.; Schoonderwoerd, K.G.; Smeets, H.J.M. Novel SLC25A32 mutation in a patient with a severe neuromuscular phenotype. Eur. J. Hum. Genet. 2017, 25, 886-888. [CrossRef]

39. Tzagoloff, A.; Jang, J.; Glerum, D.M.; Wu, M. FLX1 codes for a carrier protein involved in maintaining a proper balance of flavin nucleotides in yeast mitochondria. J. Biol. Chem. 1996, 271, 7392-7397. [CrossRef]

40. Bafunno, V.; Giancaspero, T.A.; Brizio, C.; Bufano, D.; Passarella, S.; Boles, E.; Barile, M. Riboflavin uptake and FAD synthesis in Saccharomyces cerevisiae mitochondria: Involvement of the Flx1p carrier in FAD export. J. Biol. Chem. 2004, 279, 95-102. [CrossRef]

41. Barile, M.; Passarella, S.; Bertoldi, A.; Quagliariello, E. Flavin adenine dinucleotide synthesis in isolated rat liver mitochondria caused by imported flavin mononucleotide. Arch. Biochem. Biophys. 1993, 305, 442-447. [CrossRef]

42. Giancaspero, T.A.; Wait, R.; Boles, E.; Barile, M. Succinate dehydrogenase flavoprotein subunit expression in Saccharomyces cerevisiae-involvement of the mitochondrial FAD transporter, Flx1p. FEBS J. 2008, 275, 1103-1117. [CrossRef]

43. Gietz, R.D.; Schiestl, R.H. Frozen competent yeast cells that can be transformed with high efficiency using the LiAc/SS carrier DNA/PEG method. Nat. Protoc. 2007, 2, 1-4. [CrossRef]

44. Giancaspero, T.A.; Locato, V.; De Pinto, M.C.; De Gara, L.; Barile, M. The occurrence of riboflavin kinase and FAD synthetase ensures FAD synthesis in tobacco mitochondria and maintenance of cellular redox status. FEBS J. 2009, 276, 219-231. [CrossRef]

45. Bradford, M.M. A rapid and sensitive method for the quantitation of microgram quantities of protein utilizing the principle of protein-dye binding. Anal. Biochem. 1976, 72, 248-254. [CrossRef]

46. Pallotta, M.L.; Brizio, C.; Fratianni, A.; De Virgilio, C.; Barile, M.; Passarella, S. Saccharomyces cerevisiae mitochondria can synthesise FMN and FAD from externally added riboflavin and export them to the extramitochondrial phase. FEBS Lett. 1998, 428, 245-249. [CrossRef]

47. Martin, J.; Mahlke, K.; Pfanner, N. Role of an energized inner membrane in mitochondrial protein import. Delta psi drives the movement of presequences. J. Biol. Chem. 1991, 266, 18051-18057. [CrossRef]

48. Traglia, H.M.; O'Connor, J.P.; Tung, K.S.; Dallabrida, S.; Shen, W.C.; Hopper, A.K. Nucleus-associated pools of Rna1p, the Saccharomyces cerevisiae Ran/TC4 GTPse activating protein involved in nucleus/cytosol transit. Proc. Natl. Acad. Sci. USA 1996, 93, 7667-7672. [CrossRef] [PubMed]

49. Leadsham, J.E.; Gourlay, C.W. Cytoskeletal induced apoptosis in yeast. Biochim. Biophys. Acta 2008, 1783, 1406-1412. [CrossRef] [PubMed]

50. Lombardo, A.; Cereghino, G.P.; Scheffler, I.E. Control of mRNA turnover as a mechanism of glucose repression in Saccharomyces cerevisiae. Mol. Cell. Biol. 1992, 12, 2941-2948. [CrossRef]

51. Prieto, S.; De la Cruz, B.J.; Scheffler, I.E. Glucose-regulated turnover of mRNA and the influence of poly(A) tail length on half-life. J. Biol. Chem. 2000, 275, 14155-14166. [CrossRef]

52. Polakis, E.S.; Bartley, W. Changes in the enzyme activities of Saccharomyces cerevisiae during aerobic growth on different carbon sources. Biochem. J. 1965, 97, 284-297. [CrossRef]

53. Zahedi, R.P.; Sickmann, A.; Boehm, A.M.; Winkler, C.; Zufall, N.; Schonfisch, B.; Guiard, B.; Pfanner, N.; Meisinger, C. Proteomic analysis of the yeast mitochondrial outer membrane reveals accumulation of a subclass of preproteins. Mol. Biol. Cell 2006, 17, 1436-1450. [CrossRef] [PubMed] 
54. Marc, P.; Margeot, A.; Devaux, F.; Blugeon, C.; Corral-Debrinski, M.; Jacq, C. Genome-wide analysis of mRNAs targeted to yeast mitochondria. EMBO Rep. 2002, 3, 159-164. [CrossRef] [PubMed]

55. Ahmed, A.U.; Fisher, P.R. Import of nuclear-encoded mitochondrial proteins: A cotranslational perspective. Int. Rev. Cell Mol. Biol. 2009, 273, 49-68.

56. Kellems, R.E.; Allison, V.F.; Butow, R.A. Cytoplasmic type 80 S ribosomes associated with yeast mitochondria. IV. Attachment of ribosomes to the outer membrane of isolated mitochondria. J. Cell Biol. 1975, 65, 1-14. [CrossRef]

57. Eliyahu, E.; Lesnik, C.; Arava, Y. The protein chaperone Ssa1 affects mRNA localization to the mitochondria. FEBS Lett. 2012, 586, 64-69. [CrossRef]

58. Dichtl, B.; Keller, W. Recognition of polyadenylation sites in yeast pre-mRNAs by cleavage and polyadenylation factor. The EMBO J. 2001, 20, 3197-3209. [CrossRef]

59. Zhao, J.; Hyman, L.; Moore, C. Formation of mRNA 3' ends in eukaryotes: Mechanism, regulation, and interrelationships with other steps in mRNA synthesis. Microbiol. Mol. Biol. Rev. 1999, 63, 405-445. [CrossRef]

60. Liu, H.; Han, H.; Li, J.; Wong, L. DNAFSMiner: A web-based software toolbox to recognize two types of functional sites in DNA sequences. Bioinformatics 2005, 21, 671-673. [CrossRef] [PubMed]

61. Shalgi, R.; Lapidot, M.; Shamir, R.; Pilpel, Y. A catalog of stability-associated sequence elements in 3' UTRs of yeast mRNAs. Genome Biol. 2005, 6, R86. [CrossRef] [PubMed]

62. Kellis, M.; Patterson, N.; Endrizzi, M.; Birren, B.; Lander, E.S. Sequencing and comparison of yeast species to identify genes and regulatory elements. Nature 2003, 423, 241-254. [CrossRef]

63. Jin, C.; Myers, A.M.; Tzagoloff, A. Cloning and characterization of MRP10, a yeast gene coding for a mitochondrial ribosomal protein. Curr. Genet. 1997, 31, 228-234. [CrossRef]

64. Kitakawa, M.; Graack, H.R.; Grohmann, L.; Goldschmidt-Reisin, S.; Herfurth, E.; Wittmann-Liebold, B.; Nishimura, T.; Isono, K Identification and characterization of the genes for mitochondrial ribosomal proteins of Saccharomyces cerevisiae. Eur. J. Biochem. 1997, 245, 449-456. [CrossRef]

65. Yogev, O.; Pines, O. Dual targeting of mitochondrial proteins: Mechanism, regulation and function. Biochim. Et Biophys. Acta 2011, 1808, 1012-1020. [CrossRef]

66. Bader, G.; Enkler, L.; Araiso, Y.; Hemmerle, M.; Binko, K.; Baranowska, E.; De Craene, J.O.; Ruer-Laventie, J.; Pieters, J.; Tribouillard-Tanvier, D.; et al. Assigning mitochondrial localization of dual localized proteins using a yeast Bi-Genomic Mitochondrial-Split-GFP. eLife 2020, 9, e56649. [CrossRef] [PubMed]

67. Ben-Menachem, R.; Pines, O. Detection of Dual Targeting and Dual Function of Mitochondrial Proteins in Yeast. Methods Mol. Biol. 2017, 1567, 179-195. [CrossRef] [PubMed]

68. Ben-Menachem, R.; Tal, M.; Shadur, T.; Pines, O. A third of the yeast mitochondrial proteome is dual localized: A question of evolution. Proteomics 2011, 11, 4468-4476. [CrossRef]

69. Kisslov, I.; Naamati, A.; Shakarchy, N.; Pines, O. Dual-targeted proteins tend to be more evolutionarily conserved. Mol. Biol. Evol. 2014, 31, 2770-2779. [CrossRef]

70. Dinur-Mills, M.; Tal, M.; Pines, O. Dual targeted mitochondrial proteins are characterized by lower MTS parameters and total net charge. PLoS ONE 2008, 3, e2161. [CrossRef] [PubMed]

71. Barile, M.; University of Bari 'Aldo Moro', Bari, Italy. Personal communication, 2021.

72. Lashkevich, K.A.; Dmitriev, S.E. mRNA Targeting, Transport and Local Translation in Eukaryotic Cells: From the Classical View to a Diversity of New Concepts. Mol. Biol. 2021, 1-31. [CrossRef]

73. Andreassi, C.; Riccio, A. To localize or not to localize: mRNA fate is in 3'UTR ends. Trends Cell Biol. 2009, 19, 465-474. [CrossRef]

74. Sparks, K.A.; Dieckmann, C.L. Regulation of poly(A) site choice of several yeast mRNAs. Nucleic Acids Res. 1998, 26, 4676-4687. [CrossRef]

75. Turner, R.E.; Pattison, A.D.; Beilharz, T.H. Alternative polyadenylation in the regulation and dysregulation of gene expression. Semin. Cell Dev. Biol. 2018, 75, 61-69. [CrossRef]

76. Sylvestre, J.; Vialette, S.; Corral Debrinski, M.; Jacq, C. Long mRNAs coding for yeast mitochondrial proteins of prokaryotic origin preferentially localize to the vicinity of mitochondria. Genome Biol. 2003, 4, R44. [CrossRef] [PubMed]

77. Horton, P. A simulation study of mRNA diffusion and mitochondrial localization. bioRxiv 2019. [CrossRef]

78. Gerber, A.P.; Herschlag, D.; Brown, P.O. Extensive association of functionally and cytotopically related mRNAs with Puf family RNA-binding proteins in yeast. PLoS Biol. 2004, 2, e79. [CrossRef] [PubMed]

79. Garcia-Rodriguez, L.J.; Gay, A.C.; Pon, L.A. Puf3p, a Pumilio family RNA binding protein, localizes to mitochondria and regulates mitochondrial biogenesis and motility in budding yeast. J. Cell Biol. 2007, 176, 197-207. [CrossRef] [PubMed]

80. Rowe, W.; Kershaw, C.J.; Castelli, L.M.; Costello, J.L.; Ashe, M.P.; Grant, C.M.; Sims, P.F.; Pavitt, G.D.; Hubbard, S.J. Puf3p induces translational repression of genes linked to oxidative stress. Nucleic Acids Res. 2014, 42, 1026-1041. [CrossRef] [PubMed]

81. Quenault, T.; Lithgow, T.; Traven, A. PUF proteins: Repression, activation and mRNA localization. Trends Cell Biol. 2011, 21, 104-112. [CrossRef]

82. Saint-Georges, Y.; Garcia, M.; Delaveau, T.; Jourdren, L.; Le Crom, S.; Lemoine, S.; Tanty, V.; Devaux, F.; Jacq, C. Yeast mitochondrial biogenesis: A role for the PUF RNA-binding protein Puf3p in mRNA localization. PLoS ONE 2008, 3, e2293. [CrossRef]

83. Freeberg, M.A.; Han, T.; Moresco, J.J.; Kong, A.; Yang, Y.C.; Lu, Z.J.; Yates, J.R.; Kim, J.K. Pervasive and dynamic protein binding sites of the mRNA transcriptome in Saccharomyces cerevisiae. Genome Biol. 2013, 14, R13. [CrossRef] [PubMed] 
84. Lapointe, C.P.; Stefely, J.A.; Jochem, A.; Hutchins, P.D.; Wilson, G.M.; Kwiecien, N.W.; Coon, J.J.; Wickens, M.; Pagliarini, D.J. Multi-omics Reveal Specific Targets of the RNA-Binding Protein Puf3p and Its Orchestration of Mitochondrial Biogenesis. Cell Syst. 2018, 6, 125-135.e6. [CrossRef] [PubMed]

85. Chacinska, A.; Koehler, C.M.; Milenkovic, D.; Lithgow, T.; Pfanner, N. Importing mitochondrial proteins: Machineries and mechanisms. Cell 2009, 138, 628-644. [CrossRef] [PubMed]

86. Gong, F.; Yanofsky, C. Instruction of translating ribosome by nascent peptide. Science 2002, 297, 1864-1867. [CrossRef] [PubMed] 